\title{
Implications of fiscal policy instruments in community forest management of Nepal: Issues and challenges
}

\author{
A. Paudel ${ }^{1}$ and G. Weiss ${ }^{2}$
}

\begin{abstract}
Nepalese Community Forestry has unclear and inconsistent legal provisions related to fiscal policy instruments. Based on the review of forest policy documents, and semistructured interviews and group discussions with individuals from government units, community forest user groups and traders from Parbat, Baglung and Dolakha districts of Nepal, this paper demonstrates that there are a number of issues and challenges related to fiscal policy instruments that have affected the promotion of sustainable and market-oriented management of forest resources, co-ordination between local and central government authorities, benefit sharing of forest resources, and the overall financial situation of community forest user groups. As a result, local communities do not fully benefit from their forest resources. We argue that a good co-ordination among government units, CFUGs and non-governmental organizations, and their active participation in policy making process can help to make the fiscal policy consistent and unambiguous to mitigate the existing issues and challenges.
\end{abstract}

Key words: Economic policy instrument, revenue sharing, multiple taxation, forest certification, income generation activities

$\mathbf{T}$ he Community Forestry (CF) programme in Nepal began in 1978 as an attempt by the government and aid agencies to provide an alternative way for the Department of Forests (DoF) to manage national forests by involving local people (Gilmour and Fisher, 1991). After a decade (in 1987), the concept of 'forest users group' in CF was introduced, and three years later (in 1990, after the dawn of democracy), the same group was called 'community forest users group (CFUG)' (Paudel and Vogel, 2007). However, a legal and procedural base for local people to organize themselves into a CFUG as an autonomous forest management institution was provided by the Forest Act (HMGN, 1993) and the Forest Regulation (HMGN, 1995). During the last 31 years of $\mathrm{CF}$, nearly 1.23 million ha of forest (which is about $25 \%$ of total forest land) have been handed over to more than 14,400 CFUGs (CFD, 2009).

Many organizations have been involved in supporting the CF programme in Nepal. The Ministry of Forests and Soil Conservation (MFSC) is responsible for formulating forest policy in coordination with the
National Planning Commission (NPC), while the DoF is responsible for its implementation. The Community Forestry Division (CFD), which is under DoF, is responsible for the implementation and facilitation of CF programme. The District Forest Office (DFO), also under DoF, formalizes the incorporation of users into CFUGs and hands over national forests to them. Besides, many civil society organizations, private institutions, CF networks, development partners or donors are also involved in supporting the programme (Paudel and Vogel, 2007). The Federation of Community Forest Users, Nepal (FECOFUN), which is one of the civil society organizations, has been a key player in the forestry sector policy development. In spite of the involvement of many organizations, the policy formation, implementation and field reality seem to be weakly connected in the forestry sector (Larsen $e t$ al., 2000). This situation has created inconsistencies and confusions in the provisions mentioned in policy documents and consequently has raised several issues and challenge in their implementation.

\footnotetext{
Freelance forester, Windsor, Ontario, Canada. Email: ambikapaudel@gmail.com

${ }^{2}$ University of Natural Resources and Applied Life Sciences, Vienna, Austria
} 
Policy instruments are usually classified into three broad categories: regulatory, economic, and informational (Gautam, 2006; Krott, 2005; Jann, 1981). Economic instruments are synonymously called financial (e.g. Bruijn and Hufen, 1998) or fiscal instruments (König and Dose, 1993). Fiscal instruments such as royalty, tax, subsidy and market system for forest products are the core components of Nepal's CF policy, and have significant consequences on the management of the forest resources and their benefits to local communities. However, compared to other policy instruments, the Forest Act and the Forest Regulation are less explicit in terms of fiscal policy (Kanel, 2001). We have reviewed the legal provisions of fiscal policy related to community forest management of Nepal, and discussed in this paper the existing issues and challenges while implementing the fiscal policy instruments.

\section{Materials and methods}

We reviewed the current forest policy documents: the Master Plan for the Forestry Sector (HMGN, 1989), the Forest Act (HMGN, 1993), the Forest Regulation (HMGN, 1995), the Forestry Sector Policy (HMGN, 2000), the Herbs and Non-timber Forest Products (NTFPs) Development Policy (HMGN, 2004), the Local Self Governance Act (LSGA, 1998) and its Regulation (LSGA, 1999), the Three-year Interim Plan of 2008-2010 (NPC, 2007), and CF Guidelines. In addition, semi-structured interviews and group discussions were conducted in 2008 in Baglung, Parbat and Dolakha districts, Nepal. Interviews were conducted with individuals from DFO, District Development Committee (DDC), Village Development Committee (VDC) and FECOFUN. In addition, seven forest product traders comprising four from Baglung and three from Dolakha were consulted. Group discussions were conducted in eight CFUGs (Bhodkhore, Jhauri and Hampal from Parbat; Gorucharan, Bongakhani and Watawaran Samrakchhan from Baglung; Kalobhir and Bhitteripakha from Dolakha) that are involved in forest product trade and/or in forest enterprises, and are therefore aware of the fiscal policy instruments.

\section{Results and discussion}

\section{Revenue sharing between government units and CFUGs}

There is a disputable issue related to the way the revenue from the sale of forest products is shared among the central and local government, and CFUGs (Kanel, 2007). Although LSGR has mentioned that concerned DDC gets $10 \%$ of revenue obtained by the government as royalty from forest products, it is not specific in terms of type of forests, and is also unclear whether it is from only the government managed forests (GMFs) or from community forests as well.

In case of Terai CFUGs the Forestry Sector Policy (HMGN, 2000) mentions about the revenue sharing obtained from the sale of surplus timber. According to the policy, $40 \%$ of the earning from timber sale must be deposited in the government account (central government); but nothing is mentioned about the local government units. After that policy came into effect, concerned DFOs began collecting a flat $40 \%$ tax from such sales, based on gross revenue but it is frequently referred to by forestry officials as a royalty (Bampton and Cammaert, 2007). This policy was strongly opposed by FECOFUN and after a long debate between the government authority and FECOFUN, this amount was reduced to $15 \%$ in 2004 and was restricted to only two timber species: Sal (Shorea robusta) and Khair (Acacia catechu). Local government units do not get any share of income from the above mentioned tax (Kanel, 2006). Moreover, confusion exists on how the revenue from NTFPs of community forest should be shared between the government and CFUG (Dhungana and Dahal, 2004).

It is recommended that policy provisions be amended by clearly defining the methodology on sharing of revenue obtained from community forest between government units and CFUGs. Seeing the discussions related to share of revenues (e.g. in reducing $40 \%$ to $15 \%$ ), we recommend concerned stakeholders to get involved in formulating policy to come to a common agreement and get a clearer understanding about the revenue sharing mechanism. 


\section{Multiple taxation in forest products trade}

There are contradictory provisions in controlling taxation system on forest products, between the Forest Act (HMGN, 1993) and the Local SelfGovernance Act (LSGA, 1998). The LSGA provides authority to local government (DDC) to levy a local tax on forest product, while the Forest Act allows the central government to collect tax on them. In practise, both the central and local governments impose tax in forest products trade at different forms and levels. CFUGs that sell surplus forest products have to pay $13 \%$ of royalty as VAT on products sold, excluding medicinal and aromatic plant products (MFSC, 2005). In addition, they have been paying NRs 5 per cubit feet of timber to the concerned DFO as forest development fund. CFUGs in Terai pay additional $15 \%$ tax on sales of two timber species (Sal and Khair). In case of NTFPs, the Custom Office levies $5 \%$ duty on their market price at the export point. Besides, the persons/enterprise that use the forest resource for commercial purpose have to pay a local fee up to NRs 1,000 to the concerned VDC (LSGR, 1999).

Such multiple payments are also prevalent on the export of forest products through other districts. Although the LSGR clarifies that when one DDC takes export tax on its local products, others cannot charge the same, traders have been paying levy at each district check posts while transporting the products through several districts (Kunwar et al., 2009). This way, traders end up paying more money than they legally have to pay as tax. Similar view was expressed by traders in the study area.

Contradiction between the Forest Act and the LSGA is also observed in regulatory provision, with regards to control over forest resources (USAID, 2006). Individuals from DFO and DDC stressed that both exercise their own legal right to control forest resources and taxation, and this has affected their co-ordination for forest management. Moreover, DDCs collecting export tax on products passing through their districts, is clearly against the policy provision mentioned in LSGR. In this context, it seems necessary to develop a simple and transparent taxation system and define clear legal responsibilities of government units in controlling it. In addition, concerned authorities must be trained on the taxation system and motivated just to collect legal tax on forest products trade.

\section{Benefit/revenue to CFUGs from NTFPs trade}

Although the government has the authority to impose ban on only the products from GMFs (HMGN, 1995), in practice NTFPs managed and harvested from community forests are also banned from exporting in unprocessed form. These include Cordyceps sinensis, Nardostachys grandiflora, Valeriana jatamansi, Parmelia spp., Taxus baccata, Abies spectabilis, Rawolfia serpentina, Cinamomum glaucescens and Silajitmineral exudates. Such regulation has affected the sale and export of commercial species which are abundant in community forest. In the study sites, Parmelia sp. is abundant among the banned species in most of the community forests. The CFUGs are compelled either to process themselves, or to find processing industries, both of which seem to be difficult for them. As a consequence, CFUGs are prohibited from the benefit from NTFP trade, and are discouraged in their management. Even the recent policy of the Herbs and NTFPs Development (2004) states that NTFPs cultivated in private land can be exported even in unprocessed form, but it mentions nothing about NTFPs managed or cultivated in community forest land. Hence, it seems important to develop such policy instruments that aim at sustainable management systems of NTFPs and provide optimum benefit to forest users.

Another challenge for CFUGs to get optimum benefit from NTFPs trade is the lack of provisions for their management in the operation plan (OP). Many of those CFUGs whose OPs do not sufficiently account for NTFPs management and marketing, have not been able to collect royalty from the NTFPs trade (Paudel et al., 2009), and this has lowered their gross revenue. Until the end of 2008, most of the OPs of community forests of Baglung (including studied CFUGs) did not have a detailed inventory and management plan for NTFPs. Furthermore, the dates of many OPs had already expired. The expiry was due to lack of sufficient number of forest technicians (pers. comm. with DFO staff, Baglung). As a consequence, CFUGs faced problems to sell the surplus forest product and could not collect revenue. Another situation that exists is the inclusion of management and marketing of just a few commercial species in OP. For example, the CFUGs from Dolakha whose OPs were recently revised, do not have details of management and marketing of all the commercial NTFPs, except Lokta (Daphne spp.) and Argeli (Edgeworthia gardneri). 
In addition, royalty rate of mushroom is not mentioned in their OP due to which they can not collect revenue from the sale of this species that has good local market.

In the MPFS (HMGN, 1989), although 'NTFPs development' is listed as one of its six primary programmes, the plan does not spell out research and inventory. Although the CF Inventory Guideline of 2000 (DoF, 2000) strictly mentions that only the qualified forest technicians could do the inventory, the revised guideline of 2004 (DoF, 2004) allows social workers at local level to perform community forest inventories. With this provision, CFUGs now can hire the social workers or local resource persons (LRP) and perform the inventory, and revise OPs which were backlogged due to limited forest technicians. This guideline seems to be compatible with field reality as it was prepared by DoF, involving NGOs, FECOFUN and CFUGs. During the time of field study, such a practise was seen in the CFUGs of Parbat and Dolakha districts, where FECOFUN and/or other NGOs have trained LRP to perform $\mathrm{OP}$ revision. However, revising $\mathrm{OP}$ with the inclusion of NTFPs management and marketing does not overcome the problem of collecting optimum revenue. Factors like low quantity production, inaccessibility of the sites for transportation, and lack of awareness of the legitimate ownership of the resources hinder their marketing. It is recommended that CFUGs need to be aware about the legal ownership of their forest resources and include their detailed management and marketing in OP to earn optimum revenue from NTFPs trade.

\section{Benefit to poor users from forest products}

According to the Forest Act and the Regulation, CFUGs can independently sell and distribute the forest products which are available, pursuant to the OP, by fixing their prices. However, they have to inform the concerned DFO about the price of the products, and the CFUGs feel it a cumbersome practise. In the studied CFUGs, if any forest products are to be consumed by a users' group itself, the distribution is either free of charge or is levied a price based on the consensus and it is usually found to be lower than the market price. In all of the CFUGs, products like fuelwood, fodder and leaf litter are divided on equality basis. Such forest product distribution system which does not provide more benefit to the poor has been criticized (Malla, 2001).
With regards to distribution of timber, it is found to be based on the need of timber (in terms of construction and maintenance) for users in all CFUGs. It is often the case that better-off households frequently use (and buy) more timber compared to poor, as poor households rarely build new houses or have furniture made in rural areas of Nepal. Although some CFUGs in our study sites have provision to provide timber for poor users free of charge (e.g. CFUGs from Dolakha) or in lower end of the price range (NRs 15 to 50 per cubic feet in Bhodkhore CFUG, Parbat), hardly few poor users take this benefit because of their inability to construct/renovate houses or cattle sheds. Similar result is found in a study conducted by Overseas Development Group, Nepal in 2003 in fourteen CFUGs in Nawalparasi and Rupandehi districts, where mainly rich households with larger houses purchase timber in subsidized price (Bampton and Cammaert, 2007). It seems that the poor are less benefited from forest product sale and distribution system. In this context, it is recommended to make this system more favourable towards the poor users by formulating the policy that provides easy access to poor on more forest benefits so that they can improve their livelihoods.

\section{Financial situation of CFUGs}

The Forest Regulation allows CFUGs to plant cash crops that can be the source of income generation. However, it remains silent about providing financial support to CFUGs from the government. Additionally, the Forestry Sector Policy (HMGN, 2000) mentions that local communities be encouraged to grow commercial forest crops and establish forest-based processing enterprises outside of the community forest, but it does not mention about the management of financial and technical resources required for CFUGs to establish such enterprises. This in-itself seems to be incomplete in defining the alternatives for CFUGs in improving their financial situation. In some CFUGs, external organizations have provided skill development trainings related to IGAs to users, however, users often can not utilize that skill as a profession because they can neither launch any enterprises on their own nor get any financial assistance from other organizations. Such a condition has hindered CFUGs to invest in forest-based IGAs. For example, in Bhodkhore CFUG, there is sufficient raw material and trained human resource to make Sal leaf plate that has good local market. But the CFUG is not 
running the enterprise mainly due to inadequate finance to purchase the moulding machine. CFUGs from Parbat and Baglung are conducting 'revolving fund programme' with the financial support from donor organizations mainly for livelihood improvement of poor users from the past few years, however, this amount is very little considering the number of poor users in these CFUGs, and the money has been distributed to them on priority basis to invest on IGAs. One of the favourable provisions for the poor is the recently revised CF Programme Development Guideline (DoF, 2009), according to which $35 \%$ of the CFUG' fund must be spent for poor users, either in terms of money or good, or for improvement of their livelihood.

The Forest Act mentions that at least 25\% of CFUG's fund has to be spent on forest development activities, which means the rest, can be spent in other activities. From the study area, CFUGs of Parbat and Baglung, with higher expenses of their fund in community development activities (about 50\%) and forest development works (about 30\%), were found to be in relatively poor financial situation. In contrast, CFUGs from Dolakha, in addition to other income generating activities (IGAs), are also being involved in NTFPs-based enterprise of their district through raw material supply and share investment. They have developed fund mobilization guideline, allocating $20 \%$ of the fund to enterprise development.

It seems that financial situation of CFUGs can greatly be improved by allocating higher investment in IGAs. Furthermore, utilizing a greater portion of CFUG fund in cultivation of high value NTFPs and establishment of forest-based enterprises can provide direct economic return to CFUGs in a sustainable manner. In addition, establishing 'enterprise development revolving fund' and providing orientation to CFUGs about business accounting and fund mobilization (Paudel et al., 2009) will also be important activities to improve the financial situation of CFUG.

\section{Progress on forest certification}

Nepal does not export timber in international market but NTFPs are exported mainly to India. Typically, without certification, it is difficult to export the forest product to many foreign countries. Targeting NTFPs, 14,086 ha (of 21 CFUGs) community forest land from Dolakha (including the studied CFUGs) and Bajang districts were certified in between 2004 to
2006, under Forest Stewardship Council group certification scheme. Calculations show that the certification cost in Nepal is US\$35.5 per ha, which is higher in comparison to other countries (Kandel, 2007). As CFUGs do not have adequate finance and there is a lack of financial support from the government and/or other external organizations, the forests which would have the quality to be certified, may be not certified in time. For example, Jhauri CFUG of Parbat has not been certified though the process began in 2002 by Integrated Human Ecology Project (IHEP) under a NGO known as Seed Tree Nepal. Even after certification, high cost is involved in auditing, monitoring and management of certified forests (discussion with CFUGs from certified forest of Dolakha), which is difficult to manage by CFUGs with poor financial situation.

The MPFS had committed to enhance distribution of medicinal plants and NTFPs to local and foreign market. However, the plan does not mention anything about certification. Additionally, Forestry Sector Policy of 2000 has emphasized on promoting the commercialization of NTFPs and exporting them after value-addition, but it does not mention about forest certification which is crucial for exporting forest products. In addition, financial aspect is not mentioned in the Herbs and NTFPs Development Policy (HMGN, 2004) and Three-year Interim Plan (NPC, 2007). It seems that without financial aid to CFUGs from government and/or other external agencies, certification can not be progressive and will remain a challenge for the commercial trade of valuable forest products in Nepal.

\section{Conclusion}

The review of the forest policy documents shows contradictions and confusions in their provisions related to fiscal policy in community forest management, and such provisions have created several issues and challenges in implementation. The policies does not optimally support the sustainable and market-oriented management of the forest resources and CFUGs therefore do not benefit from their forests as much as they could. In addition, poor investments in IGAs, and lack of incorporation of NTFPs management and marketing in OP has also affected the financial situation of CFUGs. We recommend amending contradictory and unclear provisions specifically on legal responsibility of government authorities regarding control over 
taxation system and revenue sharing mechanism, remove ambiguous and restrictive policies, and develop new policies to improve financial situation of CFUGs. We recommend active participation of CFUGs and non-governmental organizations during policy formulation so that aforementioned issues and challenges could be addressed properly.

\section{Acknowledgements}

The authors acknowledge Bishnu P. Acharya, Bidhur Khadka and Ganesh K. Thapa for information collection; Suman Pokhrel, Sony Baral and Kalyan Gauli for their comments and Birendra Sapkota for reviewing the paper and providing valuable suggestions.

\section{References}

Bampton, J. and Cammaert, B. 2007. Can timber rents better contribute to poverty alleviation through community forestry in the Terai region of Nepal? In $A$ Cut for the Poor (eds.) Oberndorf, R. Durst, P. Mahanty, S., Burslem, K. and Suzuki, R. Proceedings of the international conference on managing forests for poverty reduction: capturing opportunities in forest harvesting and wood processing for the benefit of the poor. Ho Chi Minh City, Vietnam, 3-6 October, 2006, FAO RAP publication number and RECOFTC Report No. 19. FAO and RECOFTC, Bangkok, Thailand.

Bruijn, H. A. and Hufen, H. A. M. 1998. The traditional approach to policy instruments. In Public Policy Instruments: Evaluating the Tools of Public Administration (eds.) Peters, B. G. and Van Nispen, F. K. M. Edward Elgar, Cheltenham, U.K. 11-13.

\section{CFD. 2009. Management Information System} Database of May 7, 2009. Community Forestry Division, Department of Forests, Kathmandu, Nepal.

Dhungana, H. P. and Dahal, S. P. 2004. Strengthening local capacity for non-timber forest products management and marketing: the need for policy reforms in community forestry in Nepal. In Twenty-Five Years of Community Forestry: Contribution in Millennium Development Goal (eds.) Kanel, K. R., Mathema, P., Kandel, B. R., Niraula, D. R., Sharma, A. R. and Gautam, M. Proceedings of fourth national conference of community forestry, August 4-6, Community Forest Division, Department of Forests, Kathmandu, Nepal, 142149.

DoF. 2000. Community Forestry Inventory Guideline. Department of Forests, Ministry of Forests and Soil Conservation, HMGN, Kathmandu, Nepal.

\section{DoF. 2004. Community Forestry Inventory} Guideline. $2^{\text {nd }}$ edition. Department of Forest, Ministry of Forests and Soil Conservation, HMGN, Kathmandu, Nepal.

\section{DoF. 2009. Community Forestry Development} Programme Guideline. $3^{\text {rd }}$ edition. Department of Forests, Ministry of Forests and Soil Conservation, HMGN, Kathmandu, Nepal.

Gautam, K. H. 2006. Forestry, politicians and powerperspectives from Nepal's forest policy. Forest Policy and Economics 8: 175-183.

Gilmour, D. and Fisher, R. 1991. Villagers, forest and foresters: the philosophy, process and practise of community forestry in Nepal. Sahayogi Press, Kathmandu, Nepal.

HMGN. 1989. Master Plan for the Forestry Sector of Nepal. Ministry of Forests and Soil Conservation, ADB/FINNIDA/HMGN, Kathmandu, Nepal.

HMGN. 1993. Forest Act of 1993. Law Books Management Board, FDP/USAID/ HMGN, Kathmandu, Nepal.

HMGN. 1995. Forest Regulation of 1995. Law Books Management Board, FDP/ USAID/ HMGN, Kathmandu, Nepal.

HMGN. 2000. Forestry Sector Policy of 2000. Law Books Management Board, FDP/USAID/ HMGN, Kathmandu, Nepal.

HMGN. 2004. Herbs and Non-timber Forest Product Development Policy of 2004. Ministry of Forests and Soil Conservation, Department of Plant Resources, Herbs and NTFPs Coordination Committee, Kathmandu, Nepal. 
Jann, W. 1981. Kategorien der Policy-Forschung. Speyerer Arbeitshefte 37, Hochschule für Verwaltungswissenschaften, Speyer, Germany.

Kandel, P. N. 2007. Effect of forest certification towards sustainable community forestry in Nepal. Banko Janakari 17 (1): 11-16.

Kanel, K. R. 2001. Forests, collective action, and policy instruments in Nepal: aligning decentralization with fiscal responsibility. In Enabling Policy Frameworks for Successful Community Based Resource Management Initiatives. Proceedings of eighth workshop on community management of forest land, Vietnam Information for Science and Technology Advance (VISTA), Hawaii, USA. 70-82.

Kanel, K. R. 2006. "Current status of Community Forestry in Nepal", paper submitted to Regional Community Forestry Training Centre for Asia and the Pacific Bangkok, Thailand. http:// www.forestrynepal.org/current-status-ofcommunity-forestry-in-nepal. Accessed on 13 November, 2006.

Kanel, K. R. 2007. Economic impacts of forest policy changes: a perspective from Nepal. The Initiation (2007):36-42.

König, K. and Dose, N. 1993. Klassifikationsansätze zum staatlichen Handeln. In Instrumente und Formen Staatlichen Handelns (eds.) König, K. and Dose, N. Heymann, Köln, Germany. 3-150.

Krott, M. 2005. Forest Policy Analysis. Springer, Dordrecht, the Netherlands.

Kunwar, C. S.; Ansari, S. A. and Luintel, H. 2009. Non-timber forest products enterprise development: regulatory challenges in Koshi Hills of Nepal. Journal of Forest and Livelihood 8 (2): 39-50.

Larsen, H. O.; Olsen, C. S. and Boon, T. E. 2000. The non-timber forest policy process in Nepal: actors, objectives and power. Forest Policy and Economics 1: 267-281.

LSGA. 1998. Local Self-Governance Act of 1998. Law Books Management Board, FDP/HMGN/ USAID, Kathmandu, Nepal.

LSGR. 1999. Local Self-Governance Regulation of 1999. Law Books Management Board, Kathmandu, Nepal.

Malla, Y. B. 2001. Changing policies and the persistence of patron-client relations in Nepal: stakeholders' responses to changes in forest policies. Environmental History 6 (2): 287-307.

MFSC. 2005. A circular about 'Tax Rate on Sale of Forest Products'. Published on Aug 12, 2005. No. 59. Ministry of Forests and Soil Conservation, Kathmandu, Nepal.

NPC. 2007. Three-Year Interim Plan of Nepal (2008-2010). National Planning Commission, Government of Nepal, Kathmandu, Nepal.

Paudel, A. and Vogel, S. 2007. Community forestry governance in Nepal: a case study of the role of service providers in a community forest users group. A Discussion Paper (DP-34-2007). University of Natural Resources and Applied Life Sciences (BOKU), Vienna, Austria.

Paudel, A.; Subedi, B. P.; Gyawali, S.; Thapa, G. K. and Sharma, M.B. 2009. Value chain analysis of NTFPs in Baglung district, Nepal. Banko Janakari 19 (2): 33-41.

USAID. 2006. Role of Natural Products in Resource Management, Poverty Alleviation and Good Governance. A Case Study of Jatamansi and Wintergreen Value Chains in Nepal. United States Agency for International Development, USAID-Nepal, Kathmandu, Nepal. 